\title{
Первинний рак печінки: захворюваність, причини, діагностика та лікування
}

\author{
V. I. DRYZHAK, H. I. NAZARKO, A. P. ZIUBROVSKYI, K. V. BARANNIKOV \\ SHEI "Ternopil State Medical University by I. Ya. Horbachevsky"
}

\section{INITIAL LIVER CANCER: MORBIDITY, CAUSES, DIAGNOSTICS AND TREATMENT}

\begin{abstract}
У роботі представлено результати досліджень показників захворюваності на первинний рак печінки (ПРП), ролі ймовірних етіологічних чинників у гепатоканцерогенезі та стану діагностики і лікування. Встановлено, що захворюваність на ПРП у Тернопільській області становить 3,6-4,1 на 100 тис. населення і вважасться низькою. Основними причинами виникнення ПРП є, вірогідно, перенесений вірусний гепатит і хронічний алкоголізм, трансформовані в цироз печінки. У 88,7 \% хворих ПРП виявлясться на пізніх стадіях хвороби. УзД і КТ повинні використовуватись як метод скринінгу ПРП при профілактичних оглядах груп ризику. Хіміотерапія в режимі системної внутрішньовенної монотерапії (5-фторурацил) малоефективна.
\end{abstract}

The work adduces the results of studies of morbidity indices with initial liver cancer (ILC), the role of propable etiologic factor in hepatocarcinogenesis and the state of diagnostics and treatment. It was determined, that the ILC morbidity in Ternopil region is 3,6-4,1 per 100 thousand of population and is deemed the low morbidity. The main reasons of ILS origin are, probably, endured viral hepatitis and chronic alcoholism, transformed in liver cirrhosis. In $\mathbf{8 8 , 7} \%$ of patients ILC occurs at late stages of the disease. USD and CT should be used as a screening method of ILC at prophylactic examinations of risk groups. Chemotherapy in a regimen of system intravenous monotherapy (5-fluorineuracil) is ineffective.

Постановка проблеми і аналіз останніх досліджень та публікацій. Первинний рак печінки (ПРП) посідає 6-те місце серед найбільш розповсюджених злоякісних пухлин і 3-тє місце - серед причин онкологічної смертності. Захворюваність на ПРП в світі становить 560 тис., а смертність - до 550 тис. випадків на рік [1]. Співвідношення захворілих до померлих становить 0,95 [2]. Особливо часто ПРП зустрічається в країнах Південно-Східної Азії, Індії, Південній Америці та Центральній Африці, де захворюваність коливається від 30 до 100 і більше випадків на 100 тис. населення.

В Україні, за даними Національного канцер-реєстру, показник захворюваності на ПРП та позапечінкових жовчних проток упродовж останніх $3-\mathrm{x}$ років становить 2,4 випадка на 100 тис. чоловічого та 2,7 - жіночого населення, а показник смертності, відповідно, 3,9 та 2,2 на 100 тис. [3]. В останнє десятиліття в Свропі та Україні зокрема відзначено невпинне зростання показників захворюваності на ПРП [4].

ПРП - багатофакторна хвороба. За даними різних авторів, $60-80 \%$ усіх випадків виникнен- ня ПРП пов'язані з інфекційним процесом, спричиненим вірусами гепатиту В і C $[5,6]$. На частоту його виникнення в інфікованих HBV i HCV впливають деякі причинні фактори, які відіграють роль коканцерогенів [7]. До них належать хронічний гепатит, цироз печінки, алкоголізм, деякі імуногенетичні чинники, екологічні полтанти, вживання наркотиків тощо. 60-90 \% хворих на ПРП в анамнезі мають вказівку на цироз печінки. Цироз печінки зумовлений HBV, підвищує ризик виникнення раку в 10 разів [8]. У 15-20\% випадків виникнення ПРП пов'язують 3 хронічним алкоголізмом.

Мета роботи: вивчити захворюваність на ПРП в Тернопільській області в останні роки, дослідити етіологічні чинники, стан діагностики та ефективність лікування первинного раку печінки.

Матеріали і методи. В роботу включено 168 хворих на ПРП та позапечінкових жовчних проток, які перебували під спостереженням у клініці онкології Тернопільського державного медичного університету впродовж останніх 4-х років (20092012 рр.). При встановленні діагнозу ПРП врахо- 
вували етіологічні фактори, клінічні прояви, особливості перебігу хвороби. Етіологічні чинники вивчали на основі анамнестичних даних, пов'язаних із перенесеним гепатитом, алкоголізмом, професійними шкідливостями тощо.

Лабораторне дослідження включало визначення в сироватці крові вмісту білірубіну, білкових фракцій, активності аланін- і аспартатамінотрансферази (АлАТ, АсАТ), лужної фосфатази. У частини хворих концентрацію $\alpha$-фетопротеїну, що $\epsilon$ маркером гепатоцелюлярного раку, в крові визначали за допомогою імуноферментного методу, а наявність HBV i HCV - з використанням цього ж методу й полімеразної ланцюгової реакції. В комплекс обстеження входили УЗД і комп'ютерна томографія. 3 метою морфологічної верифікації діагнозу були використані методи черезшкірної пункційної та прицільної лапароскопічної біопсії печінки. У ряді випадків проведена ексцизійна біопсія печінки під час лапаротомії та дослідження секційного матеріалу.

Результати досліджень та їх обговорення. Захворюваність на ПРП та позапечінкових жовчних проток за період 2009-2012 рр. коливалась у межах від 3,6 до 4,1 на 100 тис. населення. Чоловіків було 92 (54,8 \%), жінок - 76 (45,2 \%). Перевага чоловіків виявилась значно меншою, ніж в інших дослідженнях [9-11].

Таблиця 1. За віком хворі розподілились таким чином

\begin{tabular}{||c|c|c|c|c|c||}
\hline \multicolumn{7}{|c|}{ Вікові групи (n) } \\
\hline $30-39$ & $40-49$ & $50-59$ & $60-69$ & $70-79$ & $80 \mathrm{i}>$ \\
\hline 1 & 6 & 44 & 61 & 42 & 14 \\
\hline
\end{tabular}

Як видно з таблиці 1, починаючи з 50 років захворюваність на ПРП різко зростає. Найвищі показники спостерігаються у віці від 50 до 79 років $(87,5 \%)$.

Клінічний перебіг хвороби різноманітний. Провідними симптомами були прогресуюча слабість, в'ялість, втрата апетиту, схуднення, підвищення температури тіла до субфебрильних значень, ниючий біль у правому підребер'ї та епігастрії, анемія, жовтяниця. Збільшення печінки від 2 до 12 см і більше спостерігали у 108 хворих (64,4\%), асцит у 60 хворих (35,5\%).

У деяких хворих ПРП проявляється своїми ускладненнями або ознаками віддаленого метастазування (біль у хребті, в ділянці нирок, спленомегалія, блювання з домішками крові тощо). До особливостей клінічного перебігу ПРП відносять непомітний початок хвороби і неспецифічність ознак. У більшості хворих вже через 2-6 міс. (в середньому через 2-3 міс.) з'являються інтенсивний біль у животі, збільшення печінки, асцит і жовтяниця.

При пальпації печінка щільна, горбиста, нерідко відзначається новоутвореннями у вигляді вузла. У випадках розвитку ПРП на фоні цирозу (67 хворих) стан хворого різко погіршується, зростають ознаки печінкової недостатності, інтоксикація, прогресуюча втрата маси тіла.

За анамнестичними даними і даними лабораторного дослідження, із 168 хворих на ПРП вірусний гепатит із жовтяницею переніс 41 хворий $(24,2 \%)$, зловживали алкоголем понад 5 років - 38 хворих $(22,6 \%)$, поєднання цих чинників виявлено у 12 пацієнтів (7,6\%). Таким чином, більш ніж у половини пацієнтів виявлені істотні етіологічні фактори, що вплинули, вірогідно, на розвиток злоякісного процесу в печінці, причому в 53 випадках $(31,5 \%)$ це був вірусний гепатит. Другим за значенням етіологічним фактором виявився хронічний алкоголізм. Морфологічні дослідження засвідчили трансформацію цирозу печінки в рак у 67 хворих $(39,8 \%)$.

Серед макроскопічних форм ПРП найчастіше виявлялась множинна вузлувата - у 132 хворих (78,5 \%) і масивна (інфільтративна) - у 22 хворих $(13,1 \%)$.

Морфологічна верифікація здійснена у 79 хворих $(47,0 \%)$, 3 них у 64 пацієнтів $(80,9 \%)$ був гепатоцелюлярний рак, у 12 хворих $(15,2 \%)$ - холангіоцелюлярний рак і у 3 -х хворих $(3,9 \%)$ - змішаний гепатохолангіоцелюлярний рак.

Тактика діагностики ПРП “за принципом звернення хворого" є абсолютно неефективною, оскільки у переважної більшості хворих виявляється розповсюджений процес. Із 168 хворих на час звернення II стадія хвороби діагностована у 19 пацієнтів (11,3 \%), III стадія - у 82 хворих $(48,7 \%)$ і IV стадія - у 67 хворих (40,0 \%), з них у 62 хворих (36,9 \%) виявлені регіонарні і/або віддалені метастази.

В останні два десятиліття великого значення в діагностиці пухлинного ураження печінки набули сучасні променеві методи - ультразвукове дослідження (УЗД), спіральна комп’ютерна томографія (СКТ), магнітно-резонансна томографія (МРТ), позитронна емісійна томографія (ПЕТ). Впровадження зазначених методів діагностики відкрило якісно нові перспективи для раннього виявлення ПРП. УЗД, доповнене кольоровим доплерівським картуванням, через свою високу інформативність дозволяє детально вивчити структуру печінки, з високим ступенем достовірності вивчити вузлові новоутворення, диференціювати їх доброякісний чи злоякісний характер [12]. У спірних випадках після УЗД доцільна СКТ (рис. 1, 2). Ці неінвазивні променеві 


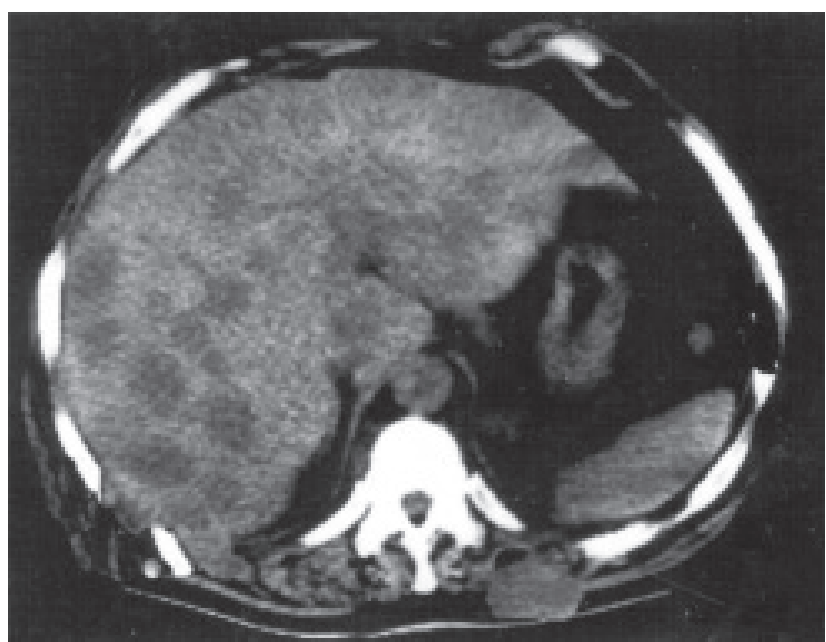

Рис. 1. КТ печінки: множинний вузлуватий ПРП на фоні цирозу.

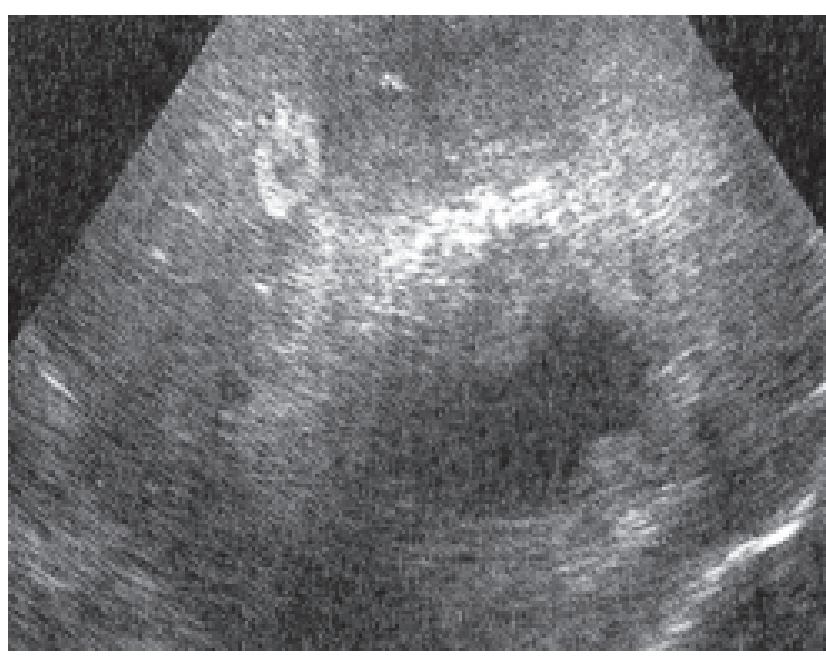

Рис. 2. УЗД печінки: масивна форма ПРП неоднорідної структури із зоною некрозу та дрібними кальцинатами [12].

методи повинні ширше використовуватись (особливо УЗД) як методи скринінгу ПРП у вікових групах після 50 років при профілактичних оглядах.

Лікування ПРП залишається складною проблемою. Вона зумовлена перш за все пізньою діагностикою. За нашими даними, з 168 хворих на ПРП в стадії Т виявлено лише 19. На вибір методу ліку-

Таблиця 2. Методи лікування хворих на ПРП

\begin{tabular}{||l|c|c||}
\hline \multicolumn{1}{|c|}{ Метод лікування } & $\begin{array}{c}\text { Кількість } \\
\text { хворих }\end{array}$ & $\begin{array}{c}\text { Середня } \\
\text { тривалість } \\
\text { життя, міс. }\end{array}$ \\
\hline Хірургічний & $7(4,2 \%)$ & $18,1 \pm 6,2$ \\
\hline $\begin{array}{l}\text { Хірургічний }+ \\
\text { хіміотерапія }\end{array}$ & $12(7,1 \%)$ & $14,3 \pm 3,1$ \\
\hline Хіміотерапія & $28(16,7 \%)$ & $9,2 \pm 2,9$ \\
\hline $\begin{array}{l}\text { Симптоматичне } \\
\text { лікування }\end{array}$ & $121(72,0 \%)$ & $7,8 \pm 3,2$ \\
\hline
\end{tabular}

вання вплинули також вік хворих, функціональний стан печінки, супутня патологія, у т. ч. "фоновий" цироз печінки та його ускладнення - асцит, кровотеча з варикозних вен стравоходу тощо.

Хірургічний метод застосований у 19 хворих $(11,3$ \%), з них у 6 пацієнтів виконані радикальні оперативні втручання (лобектомія печінки - 1 хворий, сегментарна резекція - 3 хворих, крайова резекція - 2 хворих). У 13 пацієнтів вони мали паліативний характер, спрямований на усунення жовтяниці (дренування внутрішньопечінкових і позапечінкових жовчних проток). У цих хворих додатково проведена системна хіміотерапія.

Хіміотерапія хворих на ПРП як самостійний метод набула в останні два десятиліття значного розвитку і поширення. Найефективнішою виявилась регіонарна хіміотерапія нерезектабельних пухлин. Медіана виживаності хворих після хіміоемболізації печінкової артерії була в 4-5 разів більшою порівняно 3 системною хіміоінфузією, а 3-річний строк пережили 33 \% хворих [13].

Системну хіміотерапію 5-фторурацилом ми провели у 26 хворих (16,7 \%), разова доза препарату становила 500-750 мг, сумарна - 5-7 г. Середня тривалість життя хворих склала $(9,2 \pm 2,9)$ міс., що свідчить про малу ефективність внутрішньовенної монохіміотерапії ПРП 5-фторурацилом.

Консервативне симптоматичне лікування отримав 121 хворий (72,0 \%), більшість 3 яких мала розповсюджений раковий процес або протипоказання до спеціальних методів лікування. Воно передбачало зменшення чи усунення болю, інтоксикаційного синдрому, печінкової та серцево-судинної недостатності. Середня тривалість життя цієї групи хворих склала $(7,8 \pm 3,2)$ міс.

3i 168 хворих померли в термін до 1-го року 3 часу встановлення діагнозу ПРП 129 хворих $(76,8 \%)$.

Узагальнюючи результати досліджень, можна констатувати, що гепатоканцерогенез за участю вірусів гепатиту В і С, очевидно, ініціюється поєднаним впливом низки факторів (перш за все алкоголю), а незадовільний стан ранньої (своєчасної) діагностики ПРП та невтішні результати лікування знову й знову піднімають питання профілактики, зокрема антивірусної вакцинації, та розробки і впровадження скринінгових програм. Активне застосування регіонарної поліхіміотерапії та розробка і впровадження препаратів таргетної дії, на наш погляд, значно покращать ефективність лікування ПРП.

Висновки. 1. Основними причинами виникнення ПРП є, вірогідно, перенесений вірусний гепатит та хронічний алкоголізм, трансформовані в цироз 
печінки. Пік захворюваності припадає на вікову групу 60-69 років незалежно від статі.

2. Тактика діагностики ПРП “за принципом звернення хворого” неефективна, оскільки у більшості хворих $(88,7 \%)$ пухлина виявляється в III-IV стадії, а 76,8 \% хворих помирають до 1-го року з часу встановлення діагнозу. УЗД і комп'ютерна томографія через високу інформативність

\section{СПИСОК ЛІТЕРАТУРИ}

1. Гастроэнтерология: национальное руководство / под ред. В. Т. Ивашкина, Т. Л. Лапиной. - М. : ГЭОТАР-Медиа, 2008. $-345 \mathrm{c}$.

2. Базин И. С. Гепатоцеллюлярный рак - современное состояние проблемы / И. С. Базин // Практическая онкология. -2008. - Т. 9, № 4. - С. 216-228.

3. Рак в Україні, 2009-2010. Захворюваність, смертність, показники діяльності онкологічної служби // Бюлетень Національного канцер-реєстру України. - К., 2011. - № 12. - 116 с. 4. Дьяченко А. А., Дьяченко А. Г. Гепатоцеллюлярная карцинома и вирус гепатита С // Онкология. -2001. - № 2. - С. 207 210.

5. Соринсон С. Н. Вирусные гепатиты в клинической практике / С. Н.Соринсон. - СПб. : Теза. - 1996. - 332 с.

6. Дурнов Л. А. Опухоли печени детей / Л. А. Дурнов. - М. : Медицина, 1980. - 175 с.

7. Selective accumulation of the X-transcript of hepatitis B virus in patients negative for hepatitis D surface antigen with hepatocellular carcinoma / P. Paterlini, R. Poussin, M. Kew [et повинні використовуватись як метод скринінгу ПРП при профілактичних оглядах груп ризику.

3. Лікування ПРП залишається складною проблемою через пізню діагностику та агресивний перебіг хвороби. Найкращі результати отримані після радикального хірургічного втручання. Хіміотерапія в режимі системної внутрішньовенної монотерапії 5-фторурацилом малоефективна.

al.] // Hepatology. - 1995. - Vol. 21. - P. 313-321.

8. Johson P. G., Cirrhosis and aetiology of hepatocellular carcinoma / P. G. Johson, R. Williams // G. Hepatol. - 1987. - Vol. 4. - P. 140147.

9. Попова И. В. Морфологический анализ цирроза и первичного рака печени / И. В. Попова, А. Г. Джаналиев // Архив патологии. - 1990. - Вып. 3. - С. 43-48.

10. Рак печени (анализ секционных данных) / М. Мелато, Р. Перуццо, Л. Лаурино [и др.] // Клин. медицина. - 1989. - № 11. C. $47-49$.

11. О трудностях диагностики рака печени / С. Н. Черных, В. С. Зелигман, Г. С. Радугина [и др.] // Клин. медицина. 1989. - № 10. - С. 81-84.

12. Сучасні аспекти діагностики первинного та метастатичного раку печінки / Т. С. Головко, Г. В. Лаврик, Л. А. Шевчук [та ін.] // Клин. онкология. - 2012, № 5. - С. 131-137.

13. Таразов П. Г. Регионарная терапия опухолей печени : доклад / П. Г. Таразов // Програма Міжнар. наук.-практ. конф. "Інтервенційна радіологія в онкології”. - Луцьк, 2004.

Отримано 30.01 .13 